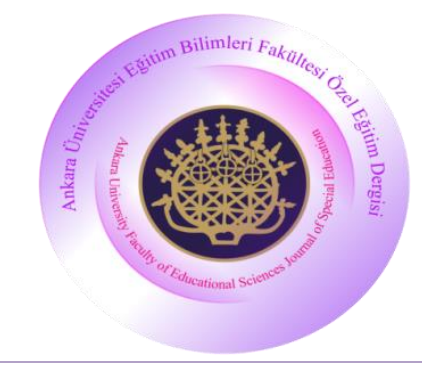

\section{Ankara Üniversitesi Eğitim Bilimleri Fakültesi Özel Eğitim Dergisi}

Yıl: 2017, Cilt: 18, Sayı: 2, Sayfa No: 253-269

DOI: 10.21565/ozelegitimdergisi.323011

\title{
Zihinsel Yetersizliği Olan Öğrencilere Toplama İşlemi Öğretiminde Doğrudan Öğretim Yöntemiyle Sunulan Nokta Belirleme Tekniği ile Sayı Doğrusu Stratejisinin Karşılaştırılması
}

\author{
Mehtap Kot \\ Abant İzzet Baysal Üniversitesi
}

\author{
Serdar Sönmez ${ }^{* * *}$ \\ Abant İzzet Baysal Üniversitesi
}

\author{
Ahmet Yıkmış \\ Abant İzzet Baysal Üniversitesi
}

Öz

\begin{abstract}
Araştırmanın amacı, zihinsel yetersizliği olan öğrencilere toplama işlemi öğretiminde nokta belirleme tekniği (touch math) ve sayı doğrusu stratejisinin etkililik ve verimlilik açısından karşılaştırılmasıdır. Araştırmaya zihinsel yetersizliği olan iki öğrenci katılmıştır. Araştırmanın bağımlı değişkeni deneklerin toplama işlemini doğru olarak yapabilme düzeyidir. Araştırmada iki bağımsız değişken bulunmaktadır. Birinci bağımsız değiş̧en nokta belirleme tekniği, ikinci bağımsız değişken ise sayı doğrusu stratejisidir. Araştırmada tek denekli araştırma desenlerinden dönüşümlü uygulamalar modeli kullanılmışıır. Araştırma sonunda zihinsel yetersizliği olan öğrencilere toplama işlemi öğretiminde nokta belirleme tekniğinin sayı doğrusu stratejisine göre daha etkili ve verimli olduğu görülmüştür.
\end{abstract}

Anahtar sözcükler: Nokta belirleme tekniği (touch math), sayı doğrusu, toplama işlemi, matematik öğretimi, zihinsel yetersizlik.

\section{$\underline{\text { Önerilen Atı Sekli }}$}

Kot, M., Sönmez, S., \& Yıkmış, A. (2017). Zihinsel yetersizliği olan öğrencilere toplama işlemi öğretiminde doğrudan öğretim yöntemiyle sunulan nokta belirleme tekniği ile sayı doğrusu stratejisinin karşılaştırılması. Ankara Üniversitesi Ĕgitim Bilimleri Fakültesi Özel Eğitim Dergisi, 18(2), 253-269.

\footnotetext{
*Sorumlu Yazar: Arş. Gör., E-posta: mehtapkot@ibu.edu.tr, http://orcid.org/0000-0002-1085-0645

**Arş. Gör., E-posta: serdarsonmez@ibu.edu.tr, http://orcid.org/0000-0002-9050-3570

***Yard. Doç. Dr., E-posta: ayikmis@ hotmail.com, http://orcid.org/0000-0002-1143-1207
} 
Yetersizliği olan bireylerin hayatlarını bağımsız bir şekilde sürdürmeleri, Türk eğitim sisteminin öncelikli hedeflerindendir. $\mathrm{Bu}$ nedenle, yetersizliği olan öğrencileri bağımsız yaşama hazırlamak için onlara işlevsel akademik becerilerin öğretilmesi gerekmektedir (Snell ve Brown, 2011). İşlevsel akademik beceriler, günlük yaşam etkinliklerini yerine getirirken kullanılan becerilerdir (Kırcaali-İftar, Ergenekon ve Uysal, 2008).

Eğitim ortamlarına bakıldığında her çocuğun var olan performans düzeyi ve gereksinimlerine göre öğretim amaçları farklılaşabilmektedir. Ancak, temel matematik becerileri arasında yer alan para kullanma, zamanı kontrol etme ve işlem yapma becerileri ile okuma-yazma becerileri, her çocuk için işlevsel akademik beceri olma özelliği göstermektedir (Snell ve Brown, 2011). Matematik konuları yetersizliği olan öğrencinin tüm hayatı boyunca işlevsel olarak kullanacağı beceri ve kavramları içermektedir. Bu bakımdan yetersizliği olan öğrencilerin eğitimlerinde matematik önemli bir yere sahiptir (Kot, 2014; Sönmez, 2014; Yıkmış, 2005).

Türkiye'de hafif ve orta düzeyde zihinsel yetersizliği olan bireyler için hazırlanan matematik öğretim programlarına bakıldığında, temel matematik konularının içeriğinde, sayma ve sayı kavramına ilişkin becerilerin hemen ardından toplama ve çıkarma gibi temel matematiksel işlemlerin öğretiminin yer aldığı görülmektedir (Dağseven-Emecen, 2008; Kırcaali-İftar ve diğ., 2008). Yetersizliği olan öğrencilere temel matematik becerileri içerisinde yer alan toplama ve çıkarma işlemlerinin öğretimi için farklı yöntem ve teknikler kullanılmaktadır. Bu yöntemler; basamaklandırılmış yöntem, doğrudan öğretim yöntemi, akran aracılı öğretim yöntemi şeklinde sıralanabilir (Yıkmış, 2005). Öğretim teknikleri ise nokta belirleme tekniği (touch math), sayı doğrusu, şema ve parmak hesabı stratejileridir (Cihak ve Foust, 2008; Rockwell, Griffin, ve Jones, 2011).

Öğretim teknikleri arasında yer alan nokta belirleme tekniği; rakamların üzerine değeri kadar nokta koymayı ve daha sonra bu noktaları sayarak işlem yapmayı gerektiren bir öğretim tekniğidir (Vinson, 2004). Bu teknik; toplama, çıkarma, çarpma ve bölme işlemlerinin öğretiminde kullanılan görsel bilginin kullanımını içermektedir (Badır, 2014; Can-Çalık, 2008; Eliçin, Dağseven-Emecen ve Yıkmış, 2013; Nuhoğlu ve Eliçin, 2012). Nokta belirleme tekniğinde rakamların üzerine konulan dokunsal noktalar sayesinde öğrenci bu noktaları görür, noktaları sayar ve işlem sonucunu bulur. Bu teknik öğrencilerin hesaplama işlemlerini sembolik ve somut düzeyde yapmalarına imkan sağlamaktadır (Simon ve Hanrahan, 2004; Vinson, 2004).
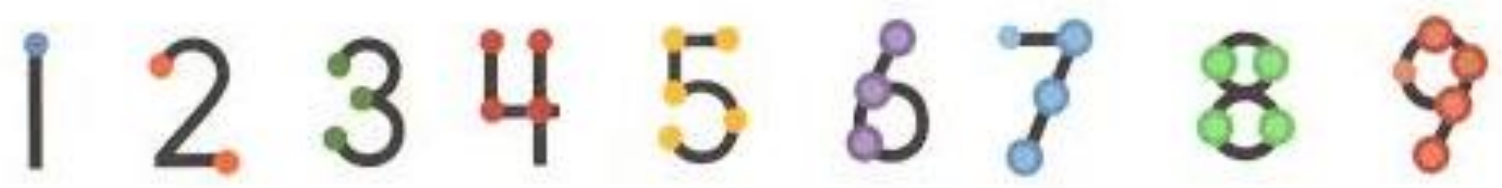

Şekil 1. Nokta belirleme tekniği referans noktaları.

Nokta belirleme tekniğinde öncelikle nokta yerleri öğrencilere öğretilir. Öğrenci parmaklar ya da çeteleler yerine, rakamların üzerindeki noktaları sayarak işlemi yapar. Öğrenci noktaların yerini öğrendikten sonra, noktalar silikleştirilir. Nokta belirleme tekniğinde Carpenter ve Moser (1984) tarafından öğrencilerin toplama işlemi yaparken kullandığı stratejiler arasında belirlenen, hepsini sayma ve toplananın üstüne sayma stratejileri kullanılmaktadır (Akt., Can-Çalık, 2008).

Alanyazında ilk olarak Kramer ve Krug (1973) tarafından özel gereksinimli bireylere aritmetik becerileri öğretiminde uygulanan nokta belirleme tekniği, daha sonraki yıllarda Bullock, Pierce ve McClelland (1989) tarafından geliştirilerek matematik müfredatı kapsamında dört temel işlem becerisinin kazandırılmasında kullanılmıştır. Alanyazında nokta belirleme tekniğinin, zihinsel yetersizlik (Badır, 2014; Çalık ve Kargın, 2010; Eliçin ve diğ., 2013; Newman, 1994; Scott, 1993), öğrenme güçlüğü (Dev, Doyle ve Valente, 2002; Dombrovski, 2010; Green, 2009; Jhaveri, Verna ve Imam, 2010, akt., Nuhoğlu ve Eliçin, 2013; Rudolph, 2008; Simon ve Hanrahan, 2004), otizm spektrum bozukluğu (Cihak ve Foust, 2008; Fletcher, Boon ve Cihak, 2010; Keskin, 2016; 
Yıkmış, 2016) ve işitme yetersizliğine (Kot, Sönmez, Yıkmış ve Cora-İnce, 2016) sahip çocuklarla yapılan uygulamalarda kullanıldığı görülmektedir.

Alanyazında zihinsel yetersizliği olan öğrencilere matematik öğretiminde nokta belirleme tekniğini kullanan araştırmacılardan Scott (1993), toplama ve çıkarma işlemlerinin öğretiminde nokta belirleme tekniğinin etkililiğini araştırmıştır. Araştırmada, tek denekli araştırma yöntemlerinden beceriler arası yoklama evreli çoklu yoklama modelini kullanılmıştır. Araştırmanın katılımcıları, zihinsel yetersizliği olan on yaşında üç öğrencidir. Araştırma bulguları, nokta belirleme tekniğinin hafif düzeyde zihinsel yetersizliği olan çocuklara toplama ve çıkarma işlemlerinin öğretiminde etkili olduğunu göstermiștir. Newman (1994) ise, Down sendromlu çocuklara temel toplama işlemi becerilerinin öğretiminde nokta belirleme tekniğinin etkililiğini araştırmıştır. Araştırmada tek denekli araştırma yöntemlerinden denekler arası çoklu yoklama modeli kullanılmıştır. Araş̧ırmaya down sendromlu dört öğrenci katılmıştır. Araştırma sonuçları, down sendromlu çocuklara temel toplama işlemi öğretiminde nokta belirleme tekniğinin etkili olduğunu göstermiştir.

Ülkemizde yapılan araştırmalar incelendiğinde zihinsel yetersizliğe sahip çocuklara toplama işlemi öğretiminde Çalık ve Kargın (2010) ve Eliçin ve diğerleri (2013), çıkarma işlemi öğretiminde ise Badır (2014)'ın çalışmaları karşımıza çıkmaktadır. Çalık ve Kargın (2010), genel eğitim sınıflarında eğitim gören zihinsel yetersizliği olan öğrencilere toplama becerilerinin öğretiminde doğrudan öğretim yaklaşımına dayalı olarak nokta belirleme tekniğiyle sunulan öğretimin etkililiğini, genellenebilirliğini ve sürekliliğini araştırmıştır. Araştırmada tek denekli araştırma modellerinden yoklama evreli denekler arası çoklu yoklama modeli kullanılmıştır. Araştırmaya 7-8 yaşları arasında, zihinsel yetersizliği olan iki kız ve bir erkek öğrenci katılmıştır. Araştırmanın bulguları, genel eğitim sınıflarında öğrenim gören hafif düzeyde zihinsel yetersizliği olan öğrencilere toplama becerilerinin öğretiminde, doğrudan öğretim yaklaşımına dayalı nokta belirleme tekniği ile sunulan öğretimin etkili, sürdürülebilir ve genellenebilir olduğunu göstermiştir. Araştırmanın sosyal geçerlik bulgularına göre, öğretmenler bu teknik hakkında olumlu görüş bildirmişlerdir. Eliçin ve diğerleri (2013) ise zihinsel yetersizliği olan öğrencilere toplama becerisinin öğretiminde doğrudan öğretim yaklaşımına dayalı nokta belirleme tekniğiyle sunulan öğretimin etkililiğini, genellenebilirliğini ve sürekliliğini araştırmışlardır. Araştırmaya 4, 9 ve 20 yaslarında zihin engelli tanısı almış iki erkek ve bir kız öğrenci dâhil edilmiştir. Araşıtırmanın yöntemi, yoklama evreli denekler arası çoklu yoklama modelidir. Araştırma bulgularına göre, zihinsel yetersizliği olan bireylere doğrudan öğretim yöntemiyle sunulan nokta belirleme tekniğinin kullanıldığ toplama işlemi öğretiminde, tekniğin etkili olduğu sonucuna ulaşılmıştır. Zihinsel yetersizliğe sahip çocuklara çıkarma işlem becerisinin öğretimine bakıldığında ise Badır (2014), sabit bekleme süreli öğretim yöntemiyle sunulan nokta belirleme tekniğinin zihinsel yetersizliği olan bireylere çıkarma işlemi öğretimindeki etkililiğini, genellenebilirliğini ve sürekliliğini araştırmıştır. Araştırmaya zihinsel yetersizliği olan üç öğrenci dahil edilmiştir. Araştırmanın yöntemi tek denekli araştırma modellerinde denekler arası yoklama evreli çoklu yoklama modelidir. Araştırma bulgularına göre sabit bekleme süreli öğretim yaklaşımıyla sunulan nokta belirleme tekniğinin çıkarma işleminin öğretiminde etkili, sürdürülebilir ve genellenebilir olduğu sonucuna ulaşılmıştır.

Ülkemizde otizm spektrum bozukluğuna (OSB) sahip çocuklara toplama işlemi öğretiminde Yıkmış (2016), çıkarma işlemi öğretiminde ise Keskin (2016) karşımıza çıkmaktadır. Keskin (2016), OSB'li olan öğrencilere çıkarma işlemi öğretiminde doğrudan öğretim yöntemiyle sunulan nokta belirleme tekniğinin etkililiği, sürdürülebilirliği ve genellenebilirliğini araştırmayı amaçlamıştır. Araştırma, tek denekli araştırma modellerinden yoklama evreli denekler arası çoklu yoklama desenine göre tasarlanmıştır. Araştırmaya OSB tanısı almış, yaşları 10 ile 11 arasında olan üç öğrenci katılmıştır. Araştırmanın bulgularına göre, doğrudan öğretim yaklaşımına dayalı olarak sunulan nokta belirleme tekniğinin OSB'li çocuklara çıkarma işleminin öğretiminde etkili, sürdürülebilir ve genellenebilir olduğunu ve öğretmenlerin bu teknikle ilgili görüşlerinin olumlu olduğunu belirlemiştir. Yıkmış (2016), OSB'li öğrencilere toplama işleminin öğretiminde nokta belirleme tekniğinin etkililiğini ve genellenebilirliğini araştırmayı amaçlamıştır. Araştırmada tek denekli araştırma modellerinden denekler arası çoklu yoklama modeli kullanılmıştır. Araştırmaya Otizm Spektrum Bozukluğu tanısı almış, yaşları 8 ile 10 
arasında değişen üç öğrenci dahil edilmiştir. Araştırma bulgularına göre, nokta belirleme tekniğinin OSB'li çocuklara toplama işleminin öğretiminde etkili olduğu sonucuna ulaşılmıştır.

Sayı doğrusu, sayının mutlak değerini, sıfır (0)'a olan uzaklığına göre görselleştirmeyi sağlayan bir araçtır. Öğrenci sayı doğrusunda sağa doğru gidildikçe sayı değerlerinin arttığını, sola doğru gidildikçe ise azaldığını görebilir. Böylece öğrenci rakamlar arasındaki işlemsel ilişkiyi somut olarak görebilmektedir (Klein, Beishuizen \& Treffers, 1998). Sayı doğrusu tekniği, sayıların sıralanmasına dayalı büyüklük küçüklük ilişkilerinin görselleştirilmesine, zihinden hesap yapmayı kolaylaştıracağına ve problemlerin şemalaştırılmasına katkıda bulunacağı düşüncesiyle geliştirilmiş bir tekniktir (Altun, 2002).

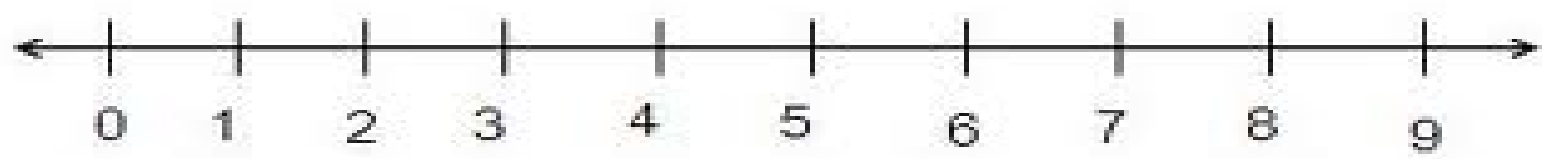

Şekil 2. Sayı doğrusu.

Sayı doğrusunda toplama işlemi yapılırken toplanan sayı pozitif ise sağa doğru, negatif ise sola doğru hareket edilir. Sonuç sıfırdan başlanarak sayı doğrusunun altına çizilir ve işlem yapılır. Toplama işlemi yaparken 0'dan başlanarak ilk sayıya kadar bir ok çizilir. İkinci sayı değeri kadar, ilk sayının üstüne sayılır ve toplam sayı bulunur. Toplam sayıyı belirtmek için ise sayı doğrusunun altından 0'dan başlayarak toplam sayıya kadar bir ok çizilir ve yapılan toplama işlemi sayı doğrusu üzerinde görselleştirilir.

Alanyazın incelendiğinde sayı doğrusunun, dört işlem (Clements, Sarama, ve DiBiase 2003; Kastberg, 2005; Wallace ve Gurganus, 2005), uzunluk (Gravemeijer, Lehrer, van Oers ve Verschaffel, 2013) ve zaman ölçme (Moone ve Groot, 2005) gibi matematik konularının öğretiminde çeşitli kullanım alanlarının olduğu görülmektedir. Bununla birlikte sayı doğrusunun etkililiğinin incelendiği araştırmalar da mevcuttur (Gonsalves ve Krawec, 2014; Izsák, Tillema ve Tunç-Pekkan, 2008).

Izsák ve diğerleri (2008), bir proje kapsamında altıncı sınıf öğrencilerine sayı doğrusu üzerinde kesirleri toplamaı öğretimi ve öğrencilerin öğrenme düzeylerine ilişkin bir durum çalışması yürütmüşlerdir. Araştırmada iki temel soruya cevap aranmıştır. Birinci soru; öğretmen ve öğrencilerin işlemi yorumlarken kullandıkları ilk bilişsel yapıları nasıldır?, ikinci soru ise, öğretmen ve öğrencilerin yorumlamaları benzer mi, farklıysa neden? Araştırma bulguları, öğretmen ve öğrenci tarafından kesirleri açıklamak ve sayı doğrusu üzerinde göstermek için kullanılan bilişsel yapıların çok detaylı analizleri sonucunda elde edilmiştir. Araştırma sonunda, yöntemlerindeki küçük farklılıkların öğretmenler için önemli olmadığı, fakat öğrencilerin öğrenmeleri için önemli sonuçları olan denemeler olduğunu göstermektedir. Gonsalves ve Krawec (2014), sözel olarak verilen problemlerin matematiksel işlemlerini belirlemede ve çözmede güçlük yaşayan öğrenme güçlüğüne sahip öğrencilerin bu sorunlarının, öğrencilerin performansını olumsuz yönde etkilediğini gözlemişlerdir. Araştırmacılar, bu güçlükleriyle başa çıkmalarını sağlamak üzere sayı doğrusunu, problem çözme stratejisi olarak kullanmayı öğrettikleri bir araştırma desenlemişlerdir. Araştırma dokuz öğrenci ile tek denekli araştırma yöntemi kullanılarak gerçekleştirilmiştir. Oturumlar haftada üç gün 35 dakikalık oturumlar halinde öğrencilerin evinde sürdürülmüştür. Araştırma sonucunda öğrencilerin büyük çoğunluğunun matematik problemlerini çözme becerilerinin arttığ görülmüştür. Fakat bir öğrencinin dört ay sonra gerçekleştirilen izleme oturumunda sayı doğrusu kullanarak problemi çözme becerisini sürdüremediği de gözlenmiştir.

Alanyazında nokta belirleme ve sayı doğrusu tekniği ile zihinsel yetersizliği olan çocuklara matematik becerilerinin öğretildiği sınırlı sayıda araştırmaya rastlanmaktadır (Badır, 2014; Çalık ve Kargın, 2010; Eliçin ve diğ., 2013; Newman, 1994; Scott, 1993). Nokta belirleme ve sayı doğrusu tekniğinin karşılaştırıldığı araştırmalara bakıldığında ise alanyazında iki araştırmaya ulaşılmıştır (Cihak ve Foust, 2008; Fletcher ve diğ., 2010). Cihak ve Foust (2008), ilkokula devam eden otizmli üç öğrenciyle tek basamaklı sayılarla tek basamaklı sayıların sonuç tek/iki basamaklı olacak şekilde toplama işlemi öğretiminde nokta belirleme tekniği ile sayı doğrusu stratejisini 
karşılaştırmışlar. Çalışma sonunda nokta belirleme tekniğinin daha etkili ve verimli olduğu belirlenmiştir. Fletcher ve diğerleri (2010), orta derecede zihinsel yetersizliği ve otizm spektrum bozukluğu olan bireylere toplama işlemlerinin öğretiminde sayı doğrusu stratejisi ile nokta belirleme tekniği kullanımının etkisini karşılaştırmışlardır. Araştırmaya orta derecede zihinsel yetersizliği ve otizm spektrum bozukluğu olan yaşları 13 ile 14 arasında değişen bir kız, iki erkek öğrenci dahil edilmiştir. Öğrencilere, tek basamaklı matematik işlemlerini sayı doğrusu stratejisi ve nokta belirleme tekniğini kullanarak nasıl çözecekleri öğretilmiştir. Yapılan bu çalışmada da nokta belirleme tekniğinin sayı doğrusu stratejisine göre daha etkili ve verimli bulunduğu belirtilmiştir.

Ülkemizde, nokta belirleme tekniği ile zihinsel yetersizliği olan çocuklara toplama işlemi (Can-Çalık, 2008; Eliçin ve diğ., 2013; Yıkmış, 2016) ve çıkarma işlemi (Badır, 2014; Keskin, 2016) öğretimi yapılan araştırmalar mevcuttur. Ancak zihinsel yetersizliği olan bireylere matematik becerilerinin öğretiminde nokta belirleme tekniği ve sayı doğrusu stratejisinin karşılaştırıldığı bir araştırmaya rastlanmamıştır. Bu bilgiler 1şığında araştırmanın amacı; literatürde etkili olduğu görülen "nokta belirleme tekniği” ve "sayı doğrusu stratejisinin" etkililik ve verimlilik açısından karşılaştırılması olarak belirlenmiştir. Bu amaç doğrultusunda; yedi ve dokuz yaşında, orta düzey zihinsel yetersizliği olan iki öğrenciye toplama becerisinin kazandırılmasında nokta belirleme tekniği ve sayı doğrusu stratejisi doğrudan öğretim yöntemi kullanılarak uygulanmıştır.

\section{Yöntem}

Bu bölümde araştırmanın modeli, araştırmanın bağımlı bağımsız değişkeleri, araştırmada kullanılan araç gereçler, uygulamanın gerçekleştirildiği ortam, araştırmanın katılımcıları, deney süreci ile verilerin toplanması ve analiz edilmesinden bahsedilmiştir.

\section{Araştırma Modeli}

Zihinsel yetersizliği olan öğrencilere toplama işlemi öğretiminde nokta belirleme tekniği (touch math) ve sayı doğrusu stratejisinin etkililik ve verimlilik açısından karşılaştırılmasının incelendiği bu araştırmada tek denekli araştırma modellerinden dönüşümlü uygulamalar modeli (Tekin-İftar, 2012) kullanılmıştır.

\section{Bağımlı ve Bağımsız Değişkenler}

Araştırmanın bağımlı değişkeni deneklerin toplama işlemini doğru yapabilme düzeyidir. Araştırmada iki bağımsız değişken bulunmaktadır. Birinci bağımsız değişken nokta belirleme tekniği iken, ikinci bağımsız değişken sayı doğrusu stratejisidir.

\section{Denekler}

Araştırmaya, Bolu ilinde ikamet eden orta düzeyde zihinsel yetersizliği olan ve araştırmanın ön koşullarını sağlayan iki öğrenci katılmıştır. Araştırmaya katılan denekleri belirlerken; somut düzeyde nesneler bir araya getirildiğinde arttığını söyleme, nesne sayma, rakamları söyleme/yazma ve sorulan rakamı gösterme, azlıkçokluk kavramları sorulduğunda gösterme ve 1-20 arasında söylenen bir sayıdan ileri birer ritmik sayabilme önkoşul özellikleri aranmıştır. Deneklerden Emir, yedi yaşında orta düzeyde zihinsel yetersizliği olan bir öğrenci olup kaynaştırma sınıfına devam etmektedir. İki senedir destek eğitim almaktadır. Destek eğitim öğretmeninden alınan bilgiye göre, Emir ile Türkçe ve matematik modülleri çalışılmaktadır. Serkan ise 9 yaşında orta düzeyde zihinsel yetersizliği olan bir öğrenci olup özel eğitim sınıfına devam etmektedir. Dört senedir destek eğitim almaktadır. Destek eğitim öğretmeninden alınan bilgiye göre, Serkan ile Türkçe, matematik ve toplumsal yaşam becerileri modülleri çalışılmaktadır. Öğretmenler ve ailelerle görüşme yapılarak, araştırmaya dahil olan bireylerle araştırma süresince touch math ve sayı doğrusu tekniklerini kullanmamaları ve matematik öğretimlerinde dört işleme yer vermemeleri hakkında bilgilendirilmişlerdir. Deneklerin demografik özellikleri Tablo 1'de verilmiştir. Deneklere uygulanan zeka testi türü ve puanlarıyla ilgili bilgilerin yer aldığı dosya, öğretmenler ve kurum tarafından paylaşılmak istenmediği için deneklerin bu özelliklerine ilişkin bilgilere ulaşılamamıştır. Sadece Rehberlik Araştırma Merkezinin koyduğu tanıların ne olduğu, yaşları ve eğitim süreleriyle ilgili öğretmenler ve aile tarafından sözel bilgi alınmıştır. Denekler için kod isim kullanılmıştır. 
Tablo 1

Araştırmaya Katılan Deneklerin Demografik Özellikleri

\begin{tabular}{cccccc}
\hline Öğrencinin Adı & Cinsiyet & Yaş & $\begin{array}{c}\text { Rehabilitasyon } \\
\text { Devam Süreleri }\end{array}$ & Tanı & Eğitim ortamı \\
\hline Emir & E & 7 yaş 8 ay & 2 & Zihinsel Yetersizlik & Kaynaştırma \\
Serkan & E & 9 yaş 2 ay & 4 & Zihinsel Yetersizlik & Özel Eğitim Sınıfi \\
\hline
\end{tabular}

\section{Araç-Gereçler}

Araştırmada nokta belirleme tekniğinin kullanıldığı öğretim oturumlarında, öncelikle öğrencilerle nokta belirleme tekniği referans numaraları çalışılmıştır (bkz. Şekil-1). Toplama işlemi öğretimi için ise araştırmacı tarafından hazırlanan A4 kağıdında 48 puntoda tüm rakamların noktalı olduğu, birbirinden farklı 10 adet toplama işleminden oluşan çalışma kağıtları kullanılmıştır. Diğer öğretim oturumlarında ise sadece alttaki rakamda noktaların bulunduğu ve noktaların tamamen kaldırıldığı, yine birbirinden farklı 10'ar adet toplama işleminin yer aldığı çalışma kağıtları kullanılmıştır. Her oturumda farklı işlemler kullanılmıştır. Sayı doğrusu stratejisinin kullanıldığı öğretim oturumlarında öncelikle öğrencilere sayı doğrusu tanıtılmıştır (bkz. Şekil-2). Öğretim oturumlarında kullanılması için araştırmacı tarafından hazırlanan her bir A4 kağıdında, birbirinden farklı beş adet sayı doğrusu şekli bulunmaktadır. Her bir oturumda toplam iki çalışma kağıdı, yani 10 farklı işlem kullanılmıştır. Her oturumda işlemler farklılaştırılmıştır. Araştırma verilerinin kaydı için veri kayıt formaları, görsel kayıtlar için ise video kamera kullanılmıştır. Ayrıca öğrencilerin annelerinden alınan bilgiyle her bir öğrencinin sevdiği beş yiyecekten oluşan pekiştireç sepetleri hazırlanmıştır.

\section{Ortam}

Araştırma, öğrencilerin devam ettikleri rehabilitasyon merkezinde bulunan $6 \mathrm{~m}^{2}$ büyüklüğündeki bireysel eğitim sınıfında yapılmıştır. Bu sınıfta bir bireysel eğitim masası, iki adet sandalye ve bir adet materyal dolabı bulunmaktadır. Odaya, araştırma verilerinin kayıt altına alınabilmesi için bir video kamera sistemi kurulmuştur.

\section{Uygulamacı}

Araştırmanın uygulama süreci, birinci yazar tarafından gerçekleştirilmiştir. Özel eğitim bölümü işitme engelliler öğretmenliği lisans, zihin engellilerin eğitimi yüksek lisans programlarından mezun ve aynı zamanda zihin engellilerin eğitimi alanında doktora programına devam etmekte olan uygulamacı, özel eğitimde zihinsel yetersizliği olan bireylere matematik öğretimi ile ilgili yüksek lisans tez çalışması hazırlamıştır.

\section{Gözlemci}

Araştırmanın gözlemcilerarası güvenirlik ve uygulama güvenirliği verileri, özel eğitim bölümü zihin engelliler öğretmenliği lisans, zihin engellilerin eğitimi yüksek lisans programlarından mezun ve aynı zamanda zihin engellilerin eğitimi alanında doktora programına devam etmekte olan bir uzman tarafından toplanmıştır. Gözlemciye araştırmanın bağımlı ve bağımsız değişkeni, öğretim ve izleme oturumlarının nasıl düzenleneceği, veri toplama formlarının nasıl kullanılacağı konusunda bilgiler verilmiştir.

\section{Deney Süreci}

Başlama düzeyi. Başlama düzeyi verilerini toplamak için öğrencilere 10 adet toplama işlemi içeren çalışma kağıtları dağıtılmıştır. Öğrencilere 'Önündeki kağıtta bulunan işlemleri yap' yönergesi verilmiştir. 15 dakika sonunda kağıtlar toplanmıştır. Öğrencinin doğru yaptığı işlemler kayıt formuna '+', yanlış yaptığı ve boş bıraktığı işlemler ise kayıt formuna '-' olarak kaydedilmiştir. Üç̧ oturum başlama düzeyi verisi toplandıktan sonra, uygulama oturumlarına geçilmiştir.

Uygulama oturumu. Öğretim oturumlarında daha önce hazırlanan iki çalışma kağıdı, yani 10 farklı toplama işlemini içeren çalışma setleriyle öğretim yapılmıştır. Doğrudan öğretim yöntemi ile sunulan Nokta Belirleme Tekniği ile hazırlanan çalışma kağıdında ilk oturum için tüm rakamlar noktalıdır. Denek ile uygulamacı 
karşılıklı oturmuş ve uygulamacı deneğe, "Şimdi seninle toplama işlemi çalışacağız. Benimle güzel bir şekilde çalışırsan, çalışma sonunda ödül sepetinden istediğini alabilirsin" diyerek ödül sepetini göstermiştir. Uygulamacı, çalışma kağıtlarından birini deneğin önüne, diğerini de kendi önüne almıştır. Uygulamacı deneğe "Beni dikkatlice izle. İşlemi ilk ben yapacağım." dedikten sonra çalışma kağıdındaki ilk işlemi göstererek, " $5+4$ kaç eder? Şimdi ben bu sayıların üzerindeki noktaları sayacağım." diyerek uygulamacı 5'in üzerinde yer alan noktaları tek tek, kalem ile göstererek saymıştır. Noktalar bitince 5'in altında yer alan 4'ün üstündeki noktaları, 5'in üstüne devam edecek şekilde saymış ve toplam sayıyı toplam çizgisi altındaki kutucuğa yazmıştır. Uygulamacı deneğe, 'Şimdi işlemi beraber yapalım. Benimle birlikte önünde yer alan işlemin rakamları üzerindeki noktaları say ve bulduğun sonucu kutucuğa yaz.' demiş̧ir. Deneğin tepkileri doğru ise sözel olarak pekiştirilmiş ve çalışma setinde yer alan bir sonraki toplama işlemine geçilmiştir. Eğer denek yanlış tepkide bulunmuş ya da hiç tepkide bulunmamış ise aynı toplama işlemi ile yönerge tekrar deneğe sunulmuş ve deneğe işlemin nasıl çözüldüğü tekrar anlatılip model olunarak işlemin doğru tamamlanması sağlanmıştır. Birinci oturumda öğrenciyle noktalı rakamlarla işlemlerin nasıl yapılacağı çalışılmıştır. İkinci, üçüncü ve dördüncü oturumda sadece ikinci rakamlar noktalı olacak şekilde çalışılmıştır. Sonrasında noktalar silikleştirilmiştir.

Sayı Doğrusu ile yapılan öğretim oturumunda da, uygulamacı ile denek karş11klı oturmuştur. Uygulamacı deneğe, "Şimdi seninle sayı doğrusunu kullanarak toplama işlemi çalışacağız. Benimle güzel bir şekilde çalışırsan, çalı̧̧ma sonunda ödül sepetinden istediğini alabilirsin." diyerek ödül sepetini göstermiştir. Uygulamacı, doğrudan öğretim yöntemi ile sunulan sayı doğrusu stratejisi ile hazırlanan çalışma kağıdının birini kendi önüne, diğerini deneğin önüne koymuştur. Uygulamacı deneğe "Beni dikkatlice izle. İşlemi ilk ben yapacağım." dedikten sonra çalışma kağıdındaki ilk işlemi göstererek, "3+2 kaç eder? Şimdi ben sayı doğrusunun üstünde işlemi yapacağım" diyerek kalemini 0'in üstüne koyar. Kalemiyle 0'dan 3'e kadar oval bir çizgi çizer. "İlk sayıya kadar geldim. Şimdi ikinci sayıyı birinci sayıya ekleyeceğim." diyerek, işlemdeki 2'yi gösterir. "iki basamak daha atlamam gerekiyor' diyerek 3'ün üzerinden iki basamak daha sayarak 5'e gelir. 3 ile 2'yi topladım 5 buldum." diyerek sayı doğrusunun altında 0 noktasından başlayarak 5'e kadar oval bir çizgi çizer. " $3+2$ kaç ediyormuş? 5 ediyormuş." diyerek sayı doğrusunun yanında yer alan toplama işleminin sonucunu yazmıştır. Uygulamacı deneğe, "Şimdi işlemi beraber yapalım. Benimle birlikte önünde yer alan işlemin rakamlarını, sayı doğrusu üzerinde işaretle ve bulduğun sonucu kutucuğa yaz." demiştir. Deneğin tepkileri doğru ise sözel olarak pekiştirilmiş ve çalışma setinde yer alan bir sonraki toplama işlemine geçilmiştir. Eğer denek yanlış tepkide bulunmuş ya da hiç tepkide bulunmamış ise aynı toplama işlemi ile yönerge tekrar deneğe sunulmuş ve deneğe işlemin nasıl çözüldüğü tekrar anlatılıp model olunarak işlemin doğru tamamlanması sağlanmıştır. Denek sayı doğrusunda yaptığı toplama işlemlerinde ölçütü karşıladığında öğretim oturumları sonlandırılmıştır.

İzleme oturumları. Öğretim sona erdikten sonraki yedinci ve yirmi birinci günde uygulamacı tarafından toplam iki oturum gerçekleştirilmiştir. İzleme oturumları, her bir öğretim oturumu için başlama düzeyi verileri gibi yapılmıştır. Öğrencilere 10 toplama işlemini içeren çalışma kağıtları dağıtılmış ve kağıttaki toplama işlemlerini yapmaları doğrultusunda yönerge verilmiştir. 15 dakika sonunda kağıtlar toplanarak analiz edilmiştir. Öğrencinin doğru yaptığı işlemler kayıt formuna '+', yanlış yaptığı ve boş bıraktı̆̆ı işlemler ise kayıt formuna '-' olarak kaydedilmiştir.

\section{Verilerin Toplanması ve Analizi}

Araştırmada etkililik ve verimlilik verileri toplanmıştır. Araştırmanın etkililik verileri, deneklerin yoklama ve izleme oturumlarında göstermiş oldukları doğru tepkilere göre hesaplanmış ve grafiksel olarak analiz edilmiştir.

Araştırmanın yoklama oturumları, toplu yoklama oturumları ve günlük yoklama oturumları olarak iki şekilde düzenlenmiş̧ir. Toplu yoklama oturumlarının ilki, başlama düzeyi verisi toplamak amacıyla toplam üç toplu yoklama oturumu şeklinde yapılmıştır. Bu aşamada öğrencilere 10 soruluk işlem kağıtları dağıtılmıştır. Toplu yoklama oturumları; tüm katılımcılar ile eşzamanlı ve birebir öğretim uygulaması olarak düzenlenmiş ve en az üç oturum üst üste kararlı veri elde edinceye kadar sürdürülmüștür. Günlük yoklama oturumları öğretim yapılan 
öğrenci ile öğretim sonrasında gerçekleştirilmiştir. Öğrenciye 10 soruluk işlem kağıdı verilmiştir. Öğrenci çalışma kâğıdını tamamladıktan sonra araştırmacı tarafından çalışma kâğıtları alınmış ve öğrencinin işlemlere vermiş olduğu doğru cevaplar kayıt edilmiştir.

Araştırmada kullanılan iki öğretimin verimlilikleri, bu öğretimlerin uygulandığı öğretim oturumlarında (a) ölçüt karşılanıncaya kadar gerçekleşen oturum sayısı (10 işlemden 8'inin doğru olarak yapılması) (b) ölçüt karşılanıncaya kadar gerçekleşen deneme sayısı, (c) ölçüt karşılanıncaya kadar oluşan hatalı tepki sayısı, (d) her deneğin ölçütü karşılamasına kadar geçen toplam süreye ilişkin verilerin karşılaştırılmasıyla belirlenmiştir.

\section{Güvenirlik}

Araştırmada, gözlemciler arası güvenirlik ve uygulama güvenirliği olmak üzere iki tür güvenirlik verisi toplanmıştır. Güvenirlik verilerinin toplanması için uygulama ortamına yerleştirilen kamera ile oturumların tümü kaydedilmiştir. Araştırmada, deneklerin hedef uyaranlara verdiği tepkiler için, tüm oturumların \%30'u rastgele belirlenip izlenerek gözlemciler arası güvenirlik verileri toplanmıştır. Araştırmada, gözlemciler arası güvenirlik; "[görüş birliği / (görüş̧ birliği + görüş ayrılığı) $\times 100$ ]" formülü kullanılarak hesaplanmıştır (Kırcaali- İftar ve Tekin, 1997). Gözlemciye öğrencinin çalışma kâğıtları ve video kayıtları verilmiş ve öğrencinin doğru cevap yüzdesini belirlemesi istenmiștir. Araştırmanın gözlemciler arası güvenirliği birinci denek için $\% 100$ ve ikinci denek için \%96 olarak bulunmuştur. House, House ve Campbell (1981), bilimsel bir araştırmada gözlemciler arası güvenirliğin \%70'in üzerinde olması gerektiğini, \%80'in üzerinde ise yeterli olduğunu, \%90'ın üzerinde ise de iyi olduğunu vurgulamaktadırlar. Buradan yola çıkarak araştırmanın gözlemciler arası güvenirlik verilerinin \%90'ın üzerinde olması araştırma için olumlu bir gelişme olarak değerlendirilebilmektedir.

Uygulama güvenirliği bağımsız değişkenin planlandığı gibi uygulanıp uygulanmadığını göstermektedir (Erbaş, 2012). Uygulama güvenirliği hesaplamasında sohbet etme, dikkat çekme, çalışmanın önemini açıklama, motive etme, ödülü tanıtma, yönerge verme, 20 saniye bekleme, denek tepkilerini kaydetme, sözel pekiştireç verme ve ödül sunma planlanan uygulamacı davranışı olarak belirlenmiştir. Uygulama güvenirliği için öğretim oturumlarının \%30'undan toplanan veriler, [gözlenen uygulamacı davranışı/planlanan uygulamacı davranışı $\times$ 100] formülü kullanılarak hesaplanmıştır (Billingsely, White ve Munson, 1980, akt., Tekin-İftar ve Kırcaali-İftar, 2006). Araştırmanın nokta belirleme tekniği uygulamasında uygulamacının iki oturumda sohbet etme davranışını yerine getirmemesi nedeniyle uygulama güvenirliği \%98 olarak hesaplanırken, sayı doğrusu öğretimi uygulama güvenirliği $\% 100$ olarak bulunmuştur.

\section{Bulgular}

\section{Öğretim Uygulamalarının Etkililik Karşılaştırması}

Şekil 3'de görüldüğü gibi Emir, her iki öğretim uygulaması için ayrı olarak toplanan başlama düzeyi oturumlarında, çalışma setlerinde yer alan toplama işlemlerine doğru tepkide bulunmamıştır. Öğrenci başarısının, nokta belirleme tekniği ile sunum yapılan birinci öğretim oturumda $\% 40$, ikinci oturumda $\% 50$, üçüncü oturumda $\% 90$, dördüncü oturumda $\% 100$, beşinci oturumda $\% 80$ ve altıncı oturumda ise $\% 100$ olduğu ve kararlı verinin elde edildiği görülmüştür. Emir, her iki izleme oturumunda da \%100 doğru cevap vermiştir. Sayı doğrusu stratejisinde ise öğrenci başarısı, birinci oturumda $\% 30$, ikinci oturumda $\% 60$, üçüncü oturumda $\% 80$, dördüncü oturumda $\% 90$, beşinci ve altıncı oturumda da $\% 80$ olarak kaydedilmiştir. Emir, sayı doğrusu stratejisi öğretiminin her iki izleme oturumunda da $\% 70$ başarı göstermiştir. 


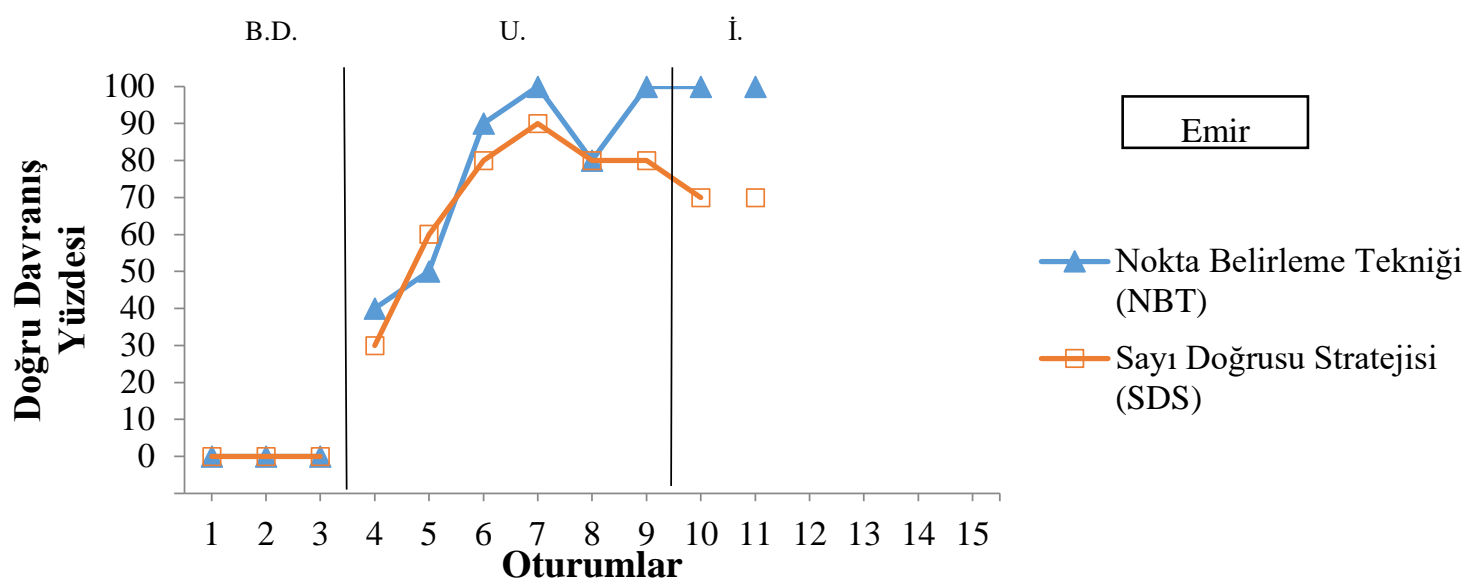

Şekil 3. Emir'in başlama, öğretim ve izleme oturumlarında toplama işlemlerine doğru tepkide bulunma yüzdeleri.

B.D.

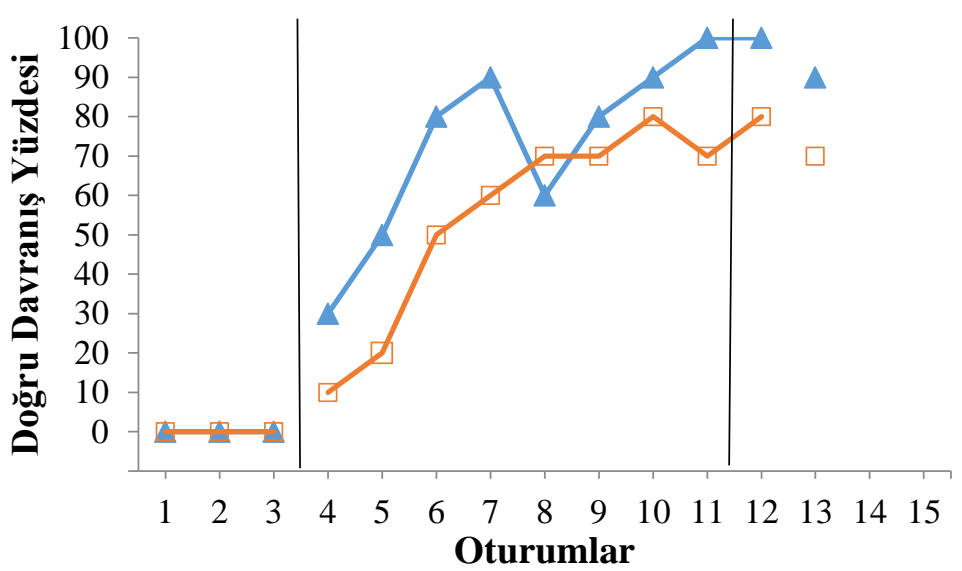

U. $\quad$ İ.

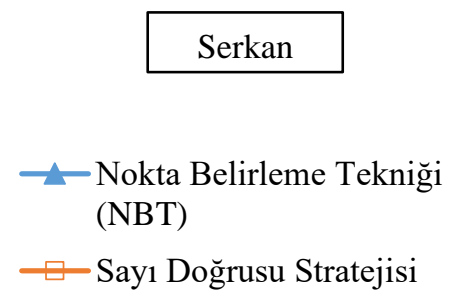

(SDS)

Şekil 4. Serkan'ın başlama, öğretim ve izleme oturumlarında toplama işlemlerine doğru tepkide bulunma yüzdeleri.

Şekil 4'de görüldüğü gibi Serkan, her iki öğretim uygulaması için ayrı olarak toplanan başlama düzeyi oturumlarında, çalışma setlerinde yer alan toplama işlemlerine doğru tepkide bulunmamıştır. Öğrencinin öğretim oturumlarında nokta belirleme tekniği ile sunum yapılan birinci oturumda $\% 30$, ikinci oturumda $\% 50$, üçüncü oturumda $\% 80$, dördüncü oturumda $\% 90$, beşinci oturumda $\% 60$ ve altıncı oturumda ise $\% 80$, yedinci oturumda $\% 90$ ve sekizinci oturumda \%100 başarı sergilediği görülmüştür. Serkan ile düzenlenen izleme oturumlarından birincisinde $\% 100$ ve ikincisinde $\% 90$ doğru cevap alınmıştır. Sayı doğrusu stratejisinde ise işlemleri doğru yapma oranı birinci oturumda $\% 10$, ikinci oturumda $\% 20$, üçüncü oturumda $\% 50$, dördüncü oturumda $\% 60$, beşinci ve altıncı oturumda $\% 70$, yedinci oturumda $\% 80$ ve sekizinci oturumda da $\% 70$ olarak kaydedilmiştir. Serkan sayı doğrusu stratejisi öğretiminin birinci izleme oturumunda $\% 80$, ikinci izleme oturumunda ise $\% 70$ oranında doğru yanıt vermiştir.

\section{Öğretim Uygulamalarının Verimlilik Karşılaştırması}

Tablo 2'de görüldüğü gibi iki deneğin de öğretim oturum sayıları aynı olmasına rağmen, Emir'in nokta belirleme tekniği ile ölçüt karşılanıncaya kadar gerçekleşen doğru deneme sayısı 46 iken, sayı doğrusu stratejisi 
ile gerçekleşen doğru deneme sayısı 42'dir. Serkan'ın da, nokta belirleme tekniği ile ölçüt karşılanıncaya kadar gerçekleşen doğru deneme sayısı 58 iken, sayı doğrusu stratejisi ile gerçekleşen doğru deneme sayısı 43'tür Araştırmada ölçüt karşılanıncaya kadar oluşan hatalı tepki sayısına baktığımızda; Emir'in nokta belirleme tekniği ile öğretim oturumlarında hatalı tepki sayısı 14 iken, sayı doğrusu ile öğretim oturumlarında 18'dir. Serkan'ın ise nokta belirleme tekniği ve sayı doğrusu stratejisi ile yapılan öğretimlerdeki hatalı tepki sayısı, nokta belirleme tekniğinde 22 iken, sayı doğrusu stratejisi ile yapılan ögretim oturumlarındaki hatalı tepki sayısı 37'dir. Öğretim oturumları süre açısından değerlendirildiğinde ise Emir, nokta belirleme tekniği ile 72 dakikada (1:12) öğretim oturumlarını tamamlamışken, sayı doğrusu stratejisi ile 79 dakikada (1:19) tamamlamıştır. Serkan ise nokta belirleme tekniği ile 86 dakikada (1:26) öğretim oturumlarını tamamlamışken, sayı doğrusu stratejisi ile 107 dakikada (1:47) tamamlamıştır.

Tablo 2

Nokta Belirleme Tekniği ve Sayı Doğrusu Stratejisi ile Sunulan Toplama İşlemi Ö̆ğretim Uygulamalarının Verimlilikleri

\begin{tabular}{|c|c|c|c|c|c|c|c|c|}
\hline \multirow[t]{2}{*}{ Denekler } & \multicolumn{2}{|c|}{$\begin{array}{c}\text { Öğretim Oturumu } \\
\text { Sayısı }\end{array}$} & \multicolumn{2}{|c|}{ Doğru Deneme Sayısı } & \multicolumn{2}{|c|}{ Hatalı Tepki Sayısı } & \multicolumn{2}{|c|}{$\begin{array}{c}\text { Süre } \\
\text { (Saat: Dakika) } \\
\end{array}$} \\
\hline & NBT & $S D S$ & $N B T$ & $S D S$ & $N B T$ & $S D S$ & $N B T$ & $S D S$ \\
\hline Emir & 6 & 6 & 46 & 42 & 14 & 18 & $1: 12$ & $1: 19$ \\
\hline Serkan & 8 & 8 & 58 & 43 & 22 & 37 & $1: 26$ & $1: 47$ \\
\hline
\end{tabular}

NBT: Nokta Belirleme Tekniği / SDS: Sayı Doğrusu Stratejisi

\section{Tartışma ve Sonuç}

Alanyazında yapılan çalışmalara bakıldığında nokta belirleme tekniğinin (Badır, 2014; Can-Çalık, 2008; Eliçin ve diğ., 2013; Keskin, 2016; Newman, 1994; Scott, 1993; Y1kmış, 2016) ve sayı doğrusu stratejisinin etkililiğini gösteren (Gonsalves ve Krawec, 2014; Izsák ve diğ., 2008;) araştırmalar mevcuttur. Yapılan uygulamalar sonucunda hem nokta belirleme tekniğinin hem de sayı doğrusu stratejisinin kullanımının etkili olduğu görülmektedir. Fakat araştırmanın amacı doğrultusunda bakıldığında nokta belirleme tekniği ile gerçekleştirilen öğretim oturumları, sayı doğrusu ile gerçekleştirilen öğretim oturumlarından etkili ve kısmen verimlidir. Araştırmanın bulguları sayı doğrusu ile nokta belirleme tekniğini kıyaslayan araştırma (Cihak ve Foust, 2008; Fletcher ve diğ., 2010) bulgularıyla da paralellik göstermektedir.

$\mathrm{Bu}$ araştırmada da nokta belirleme tekniğinin toplama işlemi öğretiminde sayı doğrusundan kısmen daha etkili olduğu bulunmuştur. Serkan'ın öğretim oturumları başarı yüzdesine baktığımızda da sayı doğrusu ile gerçekleştirilen öğretim oturumlarında veri noktalarının daha düşük olduğu görülmektedir. Serkan'ın sekizinci öğretim oturumunda yaşanan \%90'dan, \%60'a düşüşünün, sekizinci öğretim oturumunda noktaların silinmesine bağlı olduğu düşünülmektedir.

Toplama işlemi öğretiminde bu iki uygulamanın silikleştirilmesinden sonra öğrencilerin sayı doğrusu çizmesinin, rakamların üzerine değeri kadar nokta koymasından çok daha zor ve zaman alıcı olduğu düşünülmektedir. Nokta belirleme tekniğinde kullanılan noktaların, öğrencinin ilgi duyduğu nesne ile gösterilmesinin (örneğin bir çiçek ya da bir araba) öğrencinin çalışmaya olan yoğunluğunu ve ilgisini artıracağı düşünülmektedir. Zihinsel yetersizliği olan çocukların dikkat sürelerinde yaşadıkları problemler göz önüne alındığında, geleneksel yöntemlere kıyasla bu yöntemin, öğrenci dikkatini etkinliğe daha uzun süre yoğunlaştırmasından dolayı öğretmenlere ve ailelere yardımcı olacağı düşünülmektedir. Bu bakımdan zihinsel yetersizliği olan öğrencilere toplama işlemi ögretiminde nokta belirleme tekniği kullanımının çok daha verimli bir öğretim ortamı oluşturacağı düşünülmektedir.

Yapılan gözlemler sonucunda öğrencilerin nokta belirleme tekniği ile çalışırken daha mutlu oldukları ve çalışmaya daha istekli oldukları görülmüştür. Araştırma esnasında Serkan nokta belirleme tekniği öğretim oturumlarında problem yaşamazken, sayı doğrusu ile yapılan oturumlarda 'Off! Bu mu geldi yine? Noktalarla 
çalışsak olmaz mı?’ şeklinde memnuniyetsizliğini belirtmiş ve nokta belirleme tekniği ile yaptığı toplama işlemlerinde daha çok zevk aldığını göstermiştir.

Araştırmanın sınırlılıklarına bakılacak olursa, iki çocukla çalışılmış olması araştırmanın en büyük sınırlılı̆ı̆dır. Çünkü araştırmada iki deneğin olması, tek denekli araştırma desenlerinin özellikleri olan; tahmin etme, doğrulama ve yineleme basamaklarından tahmin etme ve doğrulama basamaklarını yerine getirmeye olanak sağlarken, yineleme basamağını gerçekleştirmeye olanak sağlamamaktadır. Bir diğer sınırlılık ise, öğretimi yapılan toplama ișlemlerinin sadece tek basamaklı sayılarla tek basamaklı sayıların sonuç tek basamaklı olacak şekilde hazırlanmış olmasıdır.

Araştırma sonucunda uygulamaya ve ileri araştırmalara yönelik önerilerde bulunulabilir. Öğretmenlere ve alanda çalışan uzmanlara nokta belirleme tekniği ve sayı doğrusu stratejisi ile sunulan toplama işlemi öğretimi yapılabilir ve bu iki yöntemi kullanmaları için öğretmenler cesaretlendirilebilir. Bulgulara dayalı olarak;

1. Benzer çalışmalar çıkarma, çarpma ve bölme işlemlerinin öğretiminde kullanılabilir.

2. Kullanılan bu iki öğretim yöntemi alanda çalışan öğretmen ve uzmanlara öğretilerek öğretmenlerin bu uygulamalarda ne kadar başarılı oldukları değerlendirilebilir.

3. $\mathrm{Bu}$ ögretim uygulamalarının etkililiklerini karşılaştırmak için farklı engel gruplarından deneklerle çalışılabilir. 


\section{Kaynaklar}

Altun, M. (2002). Sayı doğrusunun öğretiminde yeni bir yaklaşım. Illköğretim Online E-Dergi, 1(2), 33-39. http://dergipark.ulakbim.gov.tr/ilkonline/article/view/5000038418/5000037274 adresinden elde edilmiştir.

Badır, T. (2014). Zihin engelli bireylere çıkarma işlemi öğretiminde sabit bekleme süreli öğretimle sunulan nokta belirleme tekniğinin etkililiği (Yayınlanmamış yüksek lisans tezi). Abant İzzet Baysal Üniversitesi, Eğitim Bilimleri Enstitüsü, Bolu.

Bullock, J. K., Pierce, S., \& McClelland, L. (1989). Touch Math. Colorado Springs, CO: Innovative Learning Concepts, Inc.


ögretiminde nokta belirleme stratejisinin etkililiğinin incelenmesi (Yayınlanmamış yüksek lisans tezi). Ankara Üniversitesi, Eğitim Bilimleri Enstitüsü, Ankara.

Cihak, D. F., \& Foust, J. L. (2008). Comparing number lines and touch points to teach addition facts to students with autism. Focus on Autism and Other Developmental Disabilities, 23(3), 131-137.

Clements, D. H., Sarama, J., \& DiBiase, A. M. (Eds.). (2003). Engaging young children in mathematics: Standards for early childhood mathematics education. London: Routledge.

Çalık, N. C., \& Kargın, T. (2010). Effectiveness of the Touch Math technique in teaching addition skills to students with intellectual disabilities. International Journal of Special Education, 25(1), 195-204.

Dağseven-Emecen, D. (2008). Zihinsel yetersizliği olan öğrencilere sosyal becerilerin kazandırılmasında doğrudan ögretim ve bilişsel süreç yaklaşımları ile yapılan öğretimin etkililiklerinin ve verimliliklerinin karşılaştırılması (Yayınlanmamış doktora tezi). Gazi Üniversitesi, Eğitim Bilimleri Enstitüsü, Ankara.

Dev, P., Doyle, B. A., \& Valente, B. (2002). Labels needn't stick: “At-risk” first graders rescued with appropriate intervention. Journal of Education for Students Placed at Risk, 7(3), 327-332.

Dombrowski, C. (2010). Improving math fact acquisition of students with learning disabilities using the" Touch Math" method (Yayınlanmamış yüksek lisans tezi). Rowan University, Glassboro, New Jersey.

Eliçin, Ö., Dağseven-Emecen, D., \& Yıkmış, A. (2013). Zihin engelli çocuklara doğrudan öğretim yöntemiyle toplama işlemlerinin öğretiminde nokta belirleme tekniği kullanılarak yapılan öğretimin etkililiği. $M . \ddot{U}$. Atatürk Ĕ̌itim Fakültesi Ĕ̆itim Bilimleri Dergisi, 37(37), 118-136.

Erbaş, D. (2012). Güvenirlik. E. Tekin-İftar (Ed.), Eğitim ve davranış bilimlerinde tek-denekli araştırmalar içinde (ss. 109-132). Ankara: Türk Psikologlar Derneği Yayınları.

Fletcher, D., Boon., R. T., \& Cihak, D. F. (2010). Effects of the Touch Math program compared to a number line strategy to teach addition facts to middle school students with moderate intellectual disabilities. Education and Training in Autism and Developmental Disabilities, 45(3), 449-458.

Gonsalves, N., \& Krawec, J. (2014). Using number lines to solve math word problems: A strategy for students with learning disabilities. Learning Disabilities Research \& Practice, 29(4), 160-170.

Gravemeijer, K. P., Lehrer, R., van Oers, H. J., \& Verschaffel, L. (Eds.). (2013). Symbolizing, modeling and tool use in mathematics education (30th ed.). Springer Science and Business Media. https://books.google.com.tr/books?hl=tr\&lr=\&id=_G0yBwAAQBAJ\&oi=fnd\&pg=PA1\&dq=Symbolizi ng,+modeling+and+tool+use+in+mathematics+education+\&ots=kWe3yEVrZA\&sig=EeTmiZLo2cKNi gFZeQ9ElaKpYk4\&redir_esc=y\#v=onepage\&q=Symbolizing $\% 2 C \% 20$ modeling\%20and $\% 20$ tool\%20u se\%20in\%20mathematics\%20education\&f=false adresinden elde edilmiştir. 
ZİHINSEL YETERSIZLİĞİ OLAN ÖĞRENCİLERE TOPLAMA IŞLEMİ ÖĞRETIMINDE DOĞRUDAN ÖĞRETIM YÖNTEMIYLE SUNULAN NOKTA BELİRLEME TEKNIGGİ İLE SAYI DOĞRUSU STRATEJISINININ KARŞILAŞTIRILMASI

Green, N. D. (2009). The effectiveness of the touchmath program with fourth-and fifth-grade special educations students. http://files.eric.ed.gov/fulltext/ED507708.pdf adresinden elde edilmiştir.

House, A. E., House, B. G., \& Campbell, M. B. (1981). Measures of interobserver agreement: Calculation formula and distribution effect. Journal of Behavioral Assessment, 3(1), 37-57.

Izsák, A., Tillema, E., \& Tunç-Pekkan, Z. (2008). Teaching and learning fraction addition on number lines. Journal for Research in Mathematics Education, 39(1), 33-62.

Kastberg, S. E. (2005). Seeing the construction of a multiplicative world. For the Learning of Mathematics, 25(3), 2-6.

Keskin, (2016). Otizm spektrum bozukluğu olan öğrencilere temel çıkarma işlemi ögretiminde nokta belirleme tekniğinin etkililiği (Yayınlanmamış yüksek lisans tezi). Abant İzzet Baysal Üniversitesi, Eğitim Bilimleri Enstitüsü, Bolu.

Kırcaali-İftar, G., \& Tekin, E. (1997). Tek denekli araştırma yöntemleri (1. baskı). Ankara: Türk Psikologları Derneği.

Kırcaali-İftar, G., Ergenekon, Y., \& Uysal, A. (2008). Zihin özürlü bir öğrenciye sabit bekleme süreli öğretimle toplama ve çıkarma öğretimi. Anadolu Üniversitesi, Sosyal Bilimler Dergisi, 8(1), 309-320.

Klein, A. S., \& Beishuizen, M., \& Treffers, A. (1998). The Empty Number Line in Dutch Second Grades: Realistic Versus Gradual Program Design. Journal for Research in Mathematics Education, 29(4), 443-464.

Kot, M. (2014). Zihinsel yetersizliği olan ögrencilere problem çözme becerisinin öğretiminde şemaya dayalı ögretim stratejisinin etkililiği (Yayınlanmamış yüksek lisans tezi). Abant İzzet Baysal Üniversitesi, Eğitim Bilimleri Enstitüsü, Bolu.

Kot, M., Sönmez, S., Yıkmış, A., \& İnce, N. C. (2016). İşitme yetersizliği olan öğrencilere eldeli toplama işlemi ögretiminde nokta belirleme tekniğinin etkililiği. Current Research in Education, 2(1), 17-28.

Kramer, T., \& Krug, D. A. (1973). A rationale and procedure for teaching addition. Education and Training of the Mentally Retarded, 8(3), 140-5.

Moone, G., \& Groot, C. (2005). Time is of the essence. Teaching Children Mathematics, 12(2), 90-98.

Newman, T. M. (1994). The effectiveness of a multisensory approach for teaching addition to children with Down syndrome (Yayınlanmamış yüksek lisans tezi). McGill University, Montreal, Canada.

Nuhoğlu, H., \& Eliçin, Ö. (2013). Nokta belirleme tekniğinin (Touch Math) matematik becerilerinin öğretiminde kullanımı. Ankara Üniversitesi Eğitim Bilimleri Fakültesi Özel Eğitim Dergisi, 14(1), 21-36.

Rockwell, S. B., Griffin, C. C., \& Jones, H. A. (2011). Schema-based strategy instruction in mathematics and the word problem-solving performance of a student with autism. Focus on Autism Other Developmental Disabilities, 26(2), 87-95.

Rudolph, A. C. (2008). Using Touch Math to improve computations. Salisbury, NC: Catawba College.

Scott, K. S. (1993). Multisensory mathematics for children with mild disabilities. Exceptionally, 4(2), 97-111.

Simon, R., \& Hanrahan, J. (2004). An evaluation of the TouchMath method for teaching addition to students with learning disabilities in mathematics. European Journal of Special Needs Education, 19(2) 192-209.

Snell, M., E., \& Brown. F. (2011). Instruction of students with severe disabilities (7 $7^{\text {th }}$ ed.). Upper Saddle River, NJ: Pearson. 
Sönmez, S. (2014). Öğretmenlerin zihin engelli öğrencilerin matematik beceri kavram ve işlemlerini dĕgerlendirme sürecinde yaptıklarının belirlenmesi (Yayınlanmamış yüksek lisans tezi). Abant İzzet Baysal Üniversitesi, Eğitim Bilimleri Enstitüsü, Bolu.

Tekin-İftar, E. (2012). Eğitim ve davranış bilimlerinde tek denekli araştırmalar. Ankara: Türk Psikologlar Derneği,.

Vinson, B. M. (2004). A foundational research base for the touchmath program. Retrieved from http://www. TouchMath. com.

Wallace, A., \& Gurganus, S. (2005). Teaching for mastery of multiplication. Teaching Children Mathematics, 12(1), 26-33.

Yıkmış, A. (2005). Etkileşime dayalı matematik öğretimi. Ankara: Kök Yayıncılık.

Yıkmış, A. (2016). Effectiveness of the Touch Math technique in teaching basic addition to children with autism. Educational Sciences: Theory \& Practice, 16(3),1005-1025. 


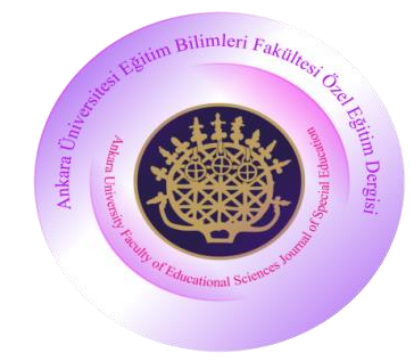

RESEARCH

\section{Ankara University Faculty of Educational Sciences Journal of Special Education}

Year: 2017, Volume: 18, No: 2, Page No: 253-269

DOI: 10.21565/ozelegitimdergisi.323011

\section{Comparison of Touch Math and Number Line Strategy Presented with Direct Instruction in Teaching Addition Problems to Students with Intellectual Disability}

\author{
Mehtap Kot \\ Abant İzzet Baysal University
}

\author{
Serdar Sönmez (iD)** \\ Abant İzzet Baysal University
}

\author{
Ahmet Yıkmış \\ Abant İzzet Baysal University
}

Abstract

The purpose of this study was to compare the effectiveness and efficiency of touch math and number line strategy in teaching basic addition to children with intellectual disability. Two students with moderate disability participated in the study. The dependent variable was the performance level of the subjects in adding skills. There are two independent variables in the study. The first independent variable was the touch math program and the second variable was the number line strategy. An alternating-treatments design across participants was utilized. Results indicated that the touch math strategy was more effective and efficient in teaching students' single-digit addition problems compared to the use of the number line strategy.

Keywords: Touch math, number line, addition problems, mathematic teaching, students with intellectual disability.

\section{Recommended Citation}

Kot, M., Sönmez, S., \& Yıkmış, A. (2017). Comparison of touch math and number line strategy presented with direct instruction in teaching addition problems to students with intellectual disability. Ankara University Faculty of Educational Sciences Journal of Special Education, 18(2), 253-269.

\footnotetext{
*Corresponding Author: Res. Ass., E-mail: mehtapkot@ibu.edu.tr, http://orcid.org/0000-0002-1085-0645

${ }^{* *}$ Res. Ass., E-mail: serdarsonmez@ibu.edu.tr, http://orcid.org/0000-0002-9050-3570

***Ass. Prof., E-mail: ayikmis@ @otmail.com, http://orcid.org/0000-0002-1143-1207
} 
Touch Math is a technique that is based on the cognitive strategies that children use in the learning process. Number Line is actually a sort of technique, making calculations to facilitate the mind and the schematization of the problem is an appropriate tool. The purpose of this study was to compare the effectiveness and efficiency of touch math and number line strategy in teaching basic addition to children with intellectual disability.

\section{Method}

The alternating treatment model among the comparison models was used in this study in which the comparison of touch math and number line strategy was examined in terms of effectiveness and efficiency in the teaching of addition to students with intellectual disability in such a way that the result of a single digit number and another single digit number would be of single digit. The dependent variable of this study is the subjects' level of ability to perform the basic addition correctly. There are two independent variables in this study. While the first independent variable is the touch math technique, the second independent variable is the number line strategy.

Two male students with the diagnosis of intellectual disability at the ages of 7 and 9 receiving support training in Bolu Private Development Special Education and Rehabilitation Centre participated in this study. While determining subjects for the participation in the research, the prerequisites of being able to say/write the numbers and show the number asked for, knowing the concepts of minority-majority, and being able to count out forward rhythmically from a number between 1 and 20 were sought.

The worksheets containing basic addition problems of 10 questions were distributed to the students in order to collect the baseline data. The students were told to do the problems on the paper. The papers were collected at the end of 15 minutes. The operations that were done correctly by the student was marked as "+" in the record form, while the operations which were done incorrectly and left blank were recorded as "-.."

The practice sessions were started after the baseline data of three sessions had been collected. The training sessions were performed right after the daily probe sessions. Teaching was performed with each target stimulus in the study sets (10 addition operations) in these sessions. All of the numbers consist of points for the first session in the worksheet prepared for the touch math technique presented with the direct teaching method. How to perform the operations with figures containing points was worked on with the student in the first session. The second, third and fourth sessions were studied in such a way that only the second figures had points. Then, the points were faded.

The practice sessions were started after the baseline data of three sessions had been collected. The training sessions were performed right after the daily probe sessions. Teaching was performed with each target stimulus in study sets (10 addition operations) in these sessions. In the training session held with the number line, the practitioner and the subject sat face-to-face. The practitioner put one of the worksheets in front of himself, and another one in front of the subject. The training sessions were finalized when the subject fulfilled the criterion in the addition operations he performed on the number line.

The monitoring sessions were held by the first researcher in the first and third weeks after the end of the training.

The data on effectiveness and efficiency were collected in this study. The effectiveness data of this study were recorded as the correct reactions given by the subjects in probe and monitoring sessions. The effectiveness of both types of training was compared by means of the graphical analysis of the data obtained from probe and monitoring sessions.

The efficiency of the two types of training used in this study was determined by comparing the data on (a) the number of sessions held until the criterion was reached in the training sessions in which these types of training were applied, (b) the number of trials performed until the criterion was reached, (c) the number of 
erroneous reactions that took place until the criterion was reached, and (d) the total period that elapsed until each subject reached the criterion.

Two types of reliability data as interobserver reliability and procedural fidelity were collected in this study. The interobserver reliability of the research was found to be $100 \%$ for the first subject and $96 \%$ for the second subject. While the procedural fidelity of the touch math practice of the research was calculated as $98 \%$, the number line teaching application reliability was found to be $100 \%$.

\section{Results}

Results indicated that the touch math strategy was more effective and efficient in teaching students singledigit addition operations compared to the use of the number line strategy.

\section{Discussion and Conclusion}

According to the study results, the training sessions held with the touch math technique are more effective and efficient than the training sessions held with the number line. The findings of this study are parallel to the research findings comparing the number line and touch math technique (Cihak and Foust, 2008; Fletcher, Boon and Cihak, 2010).

\section{Limitations}

As for the limitations of this study, its most important limitation is that it was conducted with only two children. Since the fact that there are two subjects in the research, this allows for fulfilling the prediction and verification steps of single-subject research patterns that are prediction, verification and repetition. Another limitation is that the training materials were prepared only for the basic addition operations. 